\title{
SERPINE1 -675 4G/5G polymorphism is associated with asthma severity and inhaled corticosteroid response
}

\author{
A. Dijkstra*, D.S. Postma*, M. Bruinenberg ${ }^{\#}$, C.C. van Diemen\#, H.M. Boezen־, \\ G.H. Koppelman ${ }^{+}$, W. Timens ${ }^{\S}$ and J.M. Vonk
}

ABSTRACT: Asthma is characterised by chronic airway inflammation and remodelling, which can be (partially) suppressed by inhaled corticosteroids (ICSs). Plasminogen activator inhibitor-1, encoded by the SERPINE1 gene, is the key inhibitor of the plasminogen activator system, which affects tissue repair and remodelling.

We studied associations between a functional SERPINE1 -675 4G/5G promoter polymorphism and asthma development, severity and response to ICSs.

Longitudinal cohorts of 281 asthmatics and their nonasthmatic spouses, and the general population $(n=1,390)$ were studied. No significant associations were found with asthma development and immunoglobulin (Ig)E levels, or with forced expiratory volume in $1 \mathrm{~s}$ (FEV1) in nonasthmatic controls. Asthmatic subjects carrying the SERPINE1 5G allele had higher IgE and lower lung function levels at follow-up, lower maximally attained lung function levels, and faster lung function decline compared with individuals with the 4G/4G genotype. ICS treatment showed an immediate improvement in FEV1 in asthmatics carrying the $5 G$ allele. However, these asthmatics still had the fastest rate of FEV 1 decline after initiating ICS treatment. Finally, the 5G allele was associated with a lower prevalence of complete asthma remission at follow-up.

These findings suggest that SERPINE1 is not an asthma susceptibility gene, but rather affects the severity, progression and long-term ICS response in asthma.

KEYWORDS: Asthma remission, asthma severity, genetic, inhaled corticosteroids, lung function decline, plasminogen activator inhibitor-1

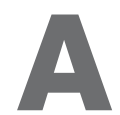
sthma is characterised by chronic airway inflammation, which contributes to characteristic structural changes, referred to as airway remodelling. A proportion of patients with asthma develops persistent airflow limitation [1-4] or shows an accelerated lung function decline $[2,5]$. Conversely, some individuals outgrow their asthma $[6,7]$. However, in patients in clinical asthma remission, ongoing airway inflammation is present, with a risk of relapse of symptoms, but a small subset of asthmatics may show complete remission later in life [8].

Airway remodelling in asthma is the process in which injured epithelial layers are replaced by extracellular matrix (ECM) instead of parenchymal cells of the same cell type. This pathological remodelling eventually leads to changes in the airway structure, including ECM deposition, subepithelial fibrosis, smooth muscle hypertrophy and goblet cell hyperplasia [9]. An imbalance between proteases and their inhibitors in response to inflammation contributes to remodelling [10,11]. The plasminogen activator system (PAS) is a regulator of ECM proteolysis, both directly through plasmin formation and indirectly through plasminmediated activation of matrix metalloproteinases (MMPs). Plasminogen activator inhibitor (PAI)-1 is a key regulator of PAS, inhibiting both fibrinolysis and MMPs in the lungs. Serum and sputum PAI-1 levels are higher in asthmatic than in healthy subjects [12, 13]. Increased activity of PAI-1 has been associated with lung fibrosis in murine models $[14,15]$ and PAI-1 is thought to play an essential role in tissue repair and remodelling [14, $16,17]$. PAI-1 is synthesised by many cells relevant to asthma and human mast cells release functionally active PAI-1 when stimulated by immunoglobulin (Ig)E receptor cross-linking [18].
AFFILIATIONS

*Depts of Pulmonology,

${ }^{\#}$ Genetics,

"Epidemiology,

+Paediatric Pulmonology, and

${ }^{\text {SPathology, University Medical }}$ Center Groningen and University of Groningen, Groningen, The Netherlands.

CORRESPONDENCE

J.M. Vonk

Dept of Epidemiology University Medical Center Groningen Hanzeplein 1

P0 box 30.001

9700 RB Groningen

The Netherlands

E-mail: j.m.vonk@umcg.nl

Received:

Nov 272010

Accepted after revision:

March 152011

First published online:

April 082011 
We have previously shown in a genome-wide screen that elevated IgE is linked to chromosome 7q21 in a Dutch families asthma study [19]. A number of candidate genes are located in this region, one of these being SERPINE1, which encodes PAI-1. Elevated serum PAI-1 levels and the SERPINE1 -675 $4 \mathrm{G} / 5 \mathrm{G}$ promoter polymorphism $[20,21]$ have previously been associated with elevated serum IgE levels in allergic diseases and allergic asthma [12, 22]. The $4 \mathrm{G} / 5 \mathrm{G}$ polymorphism has also been associated with both the development of asthma [12, 23,24 ] and asthma severity (lower lung function and increased airway hyperresponsiveness (AHR)) [12]. Importantly, the SERPINE1 4G/5G polymorphism influences PAI-1 expression, with the $4 \mathrm{G}$ allele being associated with higher PAI-1 levels $[20,21]$.

In summary, there is an association between IgE levels and a region on chromosome 7 that harbours the SERPINE1 (PAI-1) gene [19]. There is evidence for elevated PAI-1 levels in asthma [12], and a role of PAI-1 in cell migration and tissue repair [14, 16, 25-27], and airway remodelling [17], and SERPINE1 polymorphisms are associated with asthma development and severity $[12,23,24]$. Therefore, we investigated associations of SERPINE1 with asthma, IgE and airway remodelling, as reflected by asthma remission and progression, including effects on forced expiratory volume in $1 \mathrm{~s}$ (FEV1) and FEV1 decline in asthma patients. Since inhaled corticosteroids (ICSs) can reduce airway inflammation and lung function decline [5], we also assessed the interaction between SERPINE1 and ICS use. To this end, we analysed a unique longitudinal population of patients with moderate-to-severe asthma and their spouses, and a large, independent, longitudinal population-based cohort as a control group.

\section{METHODS}

\section{Study populations}

\section{Asthma population}

A cohort of 281 patients diagnosed with symptomatic asthma was initially studied in 1962-1975 at Beatrixoord Hospital (Haren, the Netherlands), a regional referral centre for patients with obstructive airways disease. At that time, all were aged $<45$ yrs and had AHR to histamine (30-s method; provocative concentration causing a $20 \%$ fall in FEV1 (PC20) $\leqslant 32 \mathrm{mg} \cdot \mathrm{mL}^{-1}$ ) [28]. Between 1991 and 1999, the patients were extensively reexamined, as well as 200 spouses of these asthmatic probands $[7,29]$. At the time of testing, all participants had no exacerbation. Maintenance asthma and allergy medication was stopped during the 2 weeks prior to the study, except for oral corticosteroid use [7].

\section{General population}

A sample of 1,390 people was selected from 2,467 subjects participating in the last survey of the Vlagtwedde-Vlaardingen cohort study in 1989-1990 [30]. This general population-based cohort study of exclusively Caucasian individuals of Dutch descent started in 1965. Participants have been followed up for 25 yrs, with surveys being performed every 3 yrs (maximum of seven surveys per participant) [31]. We genotyped DNA samples of 1,390 subjects with $>1,500 \mathrm{ng}$ isolated DNA available. There were no differences in characteristics at the last survey between the selected and nonselected groups [30].
The Medical Ethics Committee of the University Medical Center Groningen (Groningen, the Netherlands) approved all studies and all participants gave their written informed consent.

\section{Clinical evaluation}

Asthma population

Probands underwent a standardised, comprehensive evaluation for asthma at initial testing, including lung function, AHR to histamine and a symptom questionnaire [7, 29]. After initial testing, the asthmatic probands had routine check-ups for their asthma at least once a year. Data on lung function and corticosteroid use during check-ups were extracted from the medical records. Lung function data during hospital stays because of asthma exacerbations or during pregnancies were not used [5]. In the re-examination between 1991 and 1999, the same standardised methodology was used and spouses were also tested using this methodology. In addition, serum total $\mathrm{IgE}$ levels were measured and blood samples for DNA isolation were taken.

\section{General population}

During all surveys, information on respiratory symptoms and smoking status was collected using a questionnaire [32, 33], and lung function testing was performed [34]. In addition, at the last survey in 1989-1990, serum total IgE was measured and blood samples for DNA isolation were taken.

\section{DNA extraction and genotyping}

DNA was isolated from peripheral blood leukocytes using standard methods. All subjects were genotyped for the SERPINE1 -675 4G/5G polymorphism (rs1799889). For a detailed description of the methods used, refer to the online supplementary material.

\section{Statistical analyses}

The Chi-squared test was used to test for Hardy-Weinberg equilibrium. Case-control analyses (Chi-squared test) were performed on the association between the SERPINE1 4G/5G polymorphism and the presence of asthma, according to the algorithm previously published by PANHUYSEN et al. [29] (see online supplementary material). The genotype distributions of the asthmatic probands and asthmatic spouses of the asthma population were compared with the genotype distribution of: 1) the nonasthmatic spouses of the asthma population; and 2) the nonasthmatic subjects from the general population. The nonasthmatic spouses were a suitable control group as they shared environmental factors with the asthma cases, therefore excluding this confounder. In the general population cohort, the asthma phenotype according to the algorithm could not be established and, therefore, asthma was defined as ever having experienced an asthma attack, as reported on the questionnaire.

Associations between the SERPINE1 4G/5G polymorphism and serum total $\mathrm{IgE}$ were determined within the patient and control groups using one-way ANOVA. Linear regression analysis was used to evaluate the effect of the SERPINE1 polymorphism on FEV1, adjusted for age, height, sex, packyears of smoking exposure and steroid use.

The maximally attained level of FEV1 during young adulthood (i.e. the plateau phase [35]) was determined as the highest level of FEV1 reached between the ages of 20 and 35 yrs, and could only be determined in the probands of the asthma population 
(see online supplementary material). A linear regression analysis was used to determine the effect of the SERPINE1 polymorphism on the maximally attained level of FEV1 adjusted for age at maximum, sex, height and pack-years of smoking.

Linear mixed-effect models were used to investigate the effect of the SERPINE1 4G/5G polymorphism on FEV1 decline in the probands of the asthma and general populations $[5,36]$. The age of 30 yrs was the starting point of the analyses because, at that age, the maximum lung function level is generally achieved and lung function starts to decline after this point [35] (online supplementary material).

Finally, the association between complete asthma remission at the follow-up visit and the SERPINE1 genotype was determined in the asthma population. Complete asthma remission was defined as the absence of wheezing and asthma attacks, presence of normal lung function (post-bronchodilator FEV1 $>90 \%$ predicted), absence of AHR (PC20 $\geqslant 32 \mathrm{mg} \cdot \mathrm{mL}^{-1}$ ), and no use of inhaled or oral corticosteroids.

As our analyses were hypothesis driven and the outcome variables were not independent from each other (e.g. the different lung function parameters are correlated), we did not apply a sequential, classical, Bonferroni multiple-testing correction. Rather, we used an $\alpha$ of 0.025 , and results with a p-value between 0.025 and 0.05 were regarded as borderline significant.

Linear mixed-effect models of FEV1 decline were conducted with S-plus 7.0 (Insightful Corp, Seattle, WA, USA). All other analyses were conducted with SPSS (version 16; SPSS Inc., Chicago, IL, USA).

\section{RESULTS}

The clinical characteristics and the genotype distribution of the study populations are shown in table 1. The SERPINE1 4G/5G polymorphism was in Hardy-Weinberg equilibrium. 20 out of the 200 spouses of the probands had asthma themselves, and were included in the analyses of asthma and asthma phenotypes. In the general population, $143(10.3 \%)$ out of the 1,390 included subjects had ever had an asthma attack.

\section{Association with asthma and IgE}

The case-control analyses did not show statistically significant differences in genotype distribution between asthma cases and nonasthmatic controls (online supplementary table E1).

In probands and spouses with asthma, patients with the $5 \mathrm{G}$ allele $(4 \mathrm{G} / 5 \mathrm{G}$ or $5 \mathrm{G} / 5 \mathrm{G})$ had a higher serum total IgE level (geometric mean for $4 \mathrm{G} / 4 \mathrm{G} 58.9 \mathrm{IU} \cdot \mathrm{L}^{-1}$ (SD $4.1 \%$ ), and for $4 \mathrm{G} /$ 5G and 5G/5G 97.1 IU. $\left.\mathrm{L}^{-1}(\mathrm{SD} 4.6 \%) ; \mathrm{p}=0.019\right)$. There were no significant associations between the genotypes and $\operatorname{IgE}$ levels in nonasthmatic spouses, or in asthmatic or nonasthmatic subjects from the general population.

\section{Association with lung function}

Regression analyses showed that the 5G allele was significantly associated with lower FEV1 in asthma probands and affected spouses $(n=301)$ after correction for confounding variables (240 subjects had data on SERPINE1; table 2). A trend for the same association was observed in asthma subjects from the general population (online supplementary table E2). No associations between SERPINE1 genotype and lung function level were found in the control populations (online supplementary table E2).

TABLE 1 Clinical characteristics and genotype distribution of the study populations

\begin{tabular}{|c|c|c|c|}
\hline & \multicolumn{2}{|c|}{ Asthma population } & \multirow{2}{*}{$\begin{array}{c}\text { General population } \\
\text { Controls }\end{array}$} \\
\hline & Probands & Spouses & \\
\hline Subjects $\mathbf{n}$ & 281 & 200 & 1390 \\
\hline Males/females \% & $60 / 40$ & $38 / 62$ & $51 / 49$ \\
\hline Age yrs median (range) & $50(35-75)$ & $50(33-77)$ & $52(35-79)$ \\
\hline Post-BD & $82 \pm 22.4$ & $104 \pm 13.5$ & \\
\hline \multicolumn{4}{|l|}{ FEV $_{1} /$ VC $\%$} \\
\hline Pre-BD & $60 \pm 14.3$ & $77 \pm 7.3$ & $74 \pm 8.3$ \\
\hline Post-BD & $65 \pm 13.5$ & $79 \pm 7.2$ & \\
\hline Serum total IgE IU. $\mathrm{L}^{-1}$ & $81(31-267)$ & $26(10-74)$ & $27(10-66)$ \\
\hline Smoking exposure pack-yrs & $3.3(0-14.4)$ & $7.0(0-19.1)$ & $8.0(0-20.5)$ \\
\hline $4 G / 4 G$ & $59(27)$ & $60(33)$ & $366(28)$ \\
\hline $4 G / 5 G$ & $110(50)$ & $80(45)$ & $644(50)$ \\
\hline $5 G / 5 G$ & 52 (23) & 39 (22) & 292 (22) \\
\hline
\end{tabular}

Data are presented as mean $\pm \mathrm{SD}$, median (interquartile range) or $\mathrm{n}(\%)$, unless otherwise stated. Clinical characteristics of the asthma population from the time of reexamination are presented. FEV1: forced expiratory volume in $1 \mathrm{~s}$; \% pred: \% predicted; BD: bronchodilator; VC: vital capacity; Ig: immunoglobulin; ICS: inhaled corticosteroid; NA: not available. 
TABLE 2 Lung function and SERPINE1 genotypes in asthmatic probands and asthmatic spouses

\begin{tabular}{|c|c|c|c|c|c|c|c|c|c|}
\hline \multirow{2}{*}{$\begin{array}{l}\text { SERPINE1 -675 } \\
\text { genotype }^{\#}\end{array}$} & \multirow[t]{2}{*}{ Subjects $n$} & \multicolumn{4}{|c|}{ FEV $1 \mathrm{cL}$} & \multicolumn{4}{|c|}{ FEV $_{1} /$ VC $\%$} \\
\hline & & Pre-BD & $p$-value & Post-BD & $\mathrm{p}$-value & Pre-BD & p-value & Post-BD & p-value \\
\hline \multicolumn{10}{|l|}{$4 G / 5 G$} \\
\hline $4 G / 4 G$ & 70 & Reference & & Reference & & Reference & & Reference & \\
\hline $4 G / 5 G$ & 116 & $-28.5(-47.8--9.2)$ & 0.004 & $-28.1(-45.8--10.5)$ & 0.002 & $-4.6(-8.2--1.0)$ & 0.012 & $-4.5(-7.6--1.3)$ & 0.005 \\
\hline
\end{tabular}

Data are presented as regression coefficient $(95 \% \mathrm{Cl})$, unless otherwise stated. Adjusted for age, height, sex, pack-years of smoking exposure and steroid use. Bold indicates statistically significant $\mathrm{p}$-values. FEV1: forced expiratory volume in $1 \mathrm{~s}$; VC: vital capacity; BD: bronchodilator. ${ }^{\#}$ : analysed by linear regression; ${ }^{\top}$ : p-values given for the analyses on the dominant genetic model $(4 \mathrm{G} / 4 \mathrm{G}$ group compared with the combined $4 \mathrm{G} / 5 \mathrm{G}$ and $5 \mathrm{G} / 5 \mathrm{G}$ groups).

The $5 \mathrm{G}$ allele was associated with a lower maximally attained $\mathrm{FEV} 1$, i.e. asthmatic probands with the $4 \mathrm{G} / 5 \mathrm{G}$ or $5 \mathrm{G} / 5 \mathrm{G}$ genotype had a 30.4 cL (95\% CI 1.8-59.0 cL) lower FEV1 level compared with those with the $4 \mathrm{G} / 4 \mathrm{G}$ genotype (borderline significant; $\mathrm{p}=0.04$ ).

In the asthma probands, the mean FEV1 decline was substantially faster in subjects with the $4 \mathrm{G} / 5 \mathrm{G}$ or $5 \mathrm{G} / 5 \mathrm{G}$ genotype $\left(47.7 \mathrm{~mL} \cdot \mathrm{yr}^{-1}, 95 \%\right.$ CI $\left.31.1-64.2 \mathrm{~mL} \cdot \mathrm{yr}^{-1}\right)$ than the $4 \mathrm{G} / 4 \mathrm{G}$ genotype $\left(32.4 \mathrm{~mL} \cdot \mathrm{yr}^{-1}, 95 \% \mathrm{CI} 13.4-51.3 \mathrm{~mL} \cdot \mathrm{yr}^{-1}\right.$ ) (fig. 1), a difference of $15.3 \mathrm{~mL} \cdot \mathrm{yr}^{-1}\left(95 \%\right.$ CI $2.1-28.6 \mathrm{~mL} \cdot \mathrm{yr}^{-1} ; \mathrm{p}=0.024$ ) (online supplementary table E3).

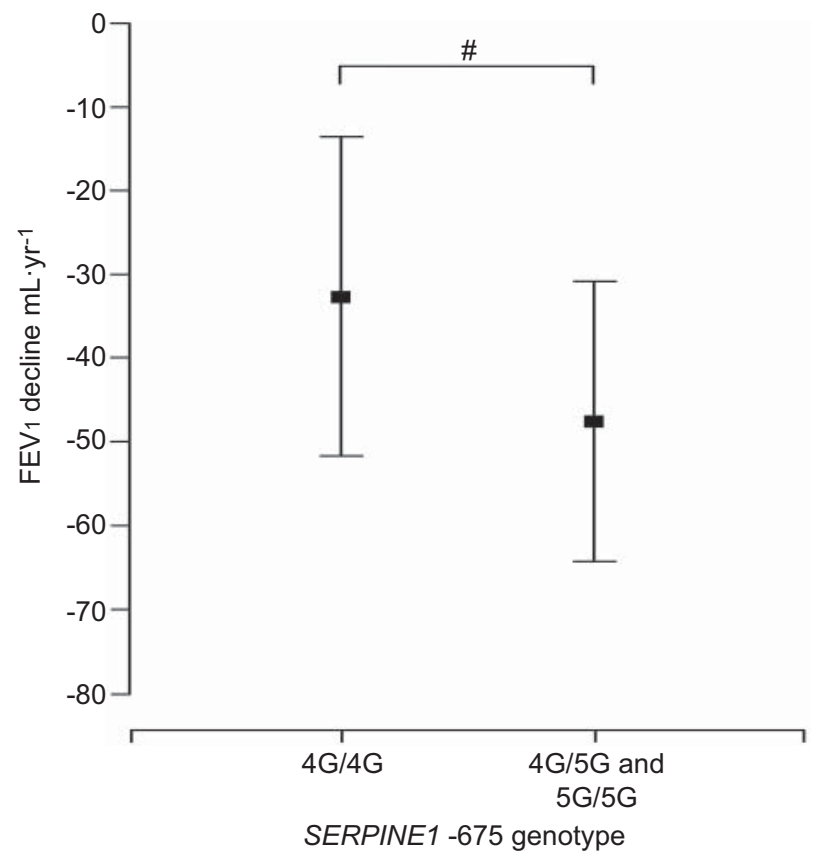

FIGURE 1. Forced expiratory volume in $1 \mathrm{~s}$ (FEV 1 ) and SERPINE1 -675 4G/5G polymorphism (dominant genetic model). Results of linear mixed-effect model analyses. Estimates and $\mathrm{p}$-values from the analyses of the dominant genetic model ( $4 \mathrm{G} / 4 \mathrm{G}$ group compared with the combined $4 \mathrm{G} / 5 \mathrm{G}$ and $5 \mathrm{G} / 5 \mathrm{G}$ groups). Corrected for use of inhaled corticosteroids. Data are presented as mean $(95 \% \mathrm{Cl})$. \#: $p=0.024$
As expected, there was an immediate improvement in FEV1 after the start of ICS treatment [37]. However, this was only present in individuals having the $4 \mathrm{G} / 5 \mathrm{G}$ or $5 \mathrm{G} / 5 \mathrm{G}$ genotypes: FEV1 increased by a mean of $189.9 \mathrm{~mL}$ (95\% CI 30.5-349.2 mL). This contrasts with asthmatics with the $4 \mathrm{G} / 4 \mathrm{G}$ genotype, i.e. a fall of $-63.1 \mathrm{~mL}(95 \%$ CI $-298.3-172.1 \mathrm{~mL}$ ) (fig. 2) and a difference of $253.0 \mathrm{~mL}(95 \%$ CI $7.9-498.0 \mathrm{~mL})$ (borderline significant; $\mathrm{p}=0.044$ ).

ICS use also slowed the rate of FEV1 decline over time by $31.2 \mathrm{~mL} \cdot \mathrm{yr}^{-1}\left(95 \% 12.8-49.5 \mathrm{~mL} \cdot \mathrm{yr}^{-1}\right)$. This effect was comparable between the genotypes $(4 \mathrm{G} / 4 \mathrm{G}$ versus $4 \mathrm{G} / 5 \mathrm{G}$ or $5 \mathrm{G} / 5 \mathrm{G}$; $\mathrm{p}=0.28)$.

In the general population, SERPINE1 genotypes were not significantly associated with FEV1 decline over time $(4 \mathrm{G} / 4 \mathrm{G}$ versus $4 \mathrm{G} / 5 \mathrm{G}$ or $5 \mathrm{G} / 5 \mathrm{G}$ : $-0.8 \mathrm{~mL} \cdot \mathrm{yr}^{-1}\left(95 \% \mathrm{CI}-3.7-2.0 \mathrm{~mL} \cdot \mathrm{yr}^{-1}\right)$ faster decline in nonasthmatics and $0.2 \mathrm{~mL} \cdot \mathrm{yr}^{-1}(95 \% \mathrm{CI}-9.1-$ $9.5 \mathrm{~mL} \cdot \mathrm{yr}^{-1}$ ) less rapid decline in asthmatics).

\section{Association with complete asthma remission}

The prevalence of complete asthma remission at follow-up in the 281 asthmatic probands was $11.7 \% \quad(n=33)$. Complete asthma remission was more prevalent in subjects with the $4 \mathrm{G} /$ $4 \mathrm{G}$ genotype $(20.3 \%)$ compared with subjects with the $4 \mathrm{G} / 5 \mathrm{G}$ genotype $(10.9 \%)$ or the $5 \mathrm{G} / 5 \mathrm{G}$ genotype $(3.8 \%)(p=0.025)$.

\section{DISCUSSION}

This study suggests that the functional SERPINE1 4G/5G polymorphism is associated with the severity, but not the presence, of asthma. Asthmatics with the 5G allele had a significantly higher serum total IgE level, a lower FEV1, a lower maximally attained FEV1 during young adulthood and a faster annual FEV1 decline. Data in the general population confirmed the association between the 5G allele and lower FEV1 in asthmatics only. Interestingly, treatment with ICSs was associated with an immediate FEV1 improvement in asthmatics with the SERPINE1 5G genotype, a finding that was absent in those with the $4 \mathrm{G} / 4 \mathrm{G}$ genotype. Notably, we suggest the $5 \mathrm{G}$ allele was also associated with a lower prevalence of complete asthma remission at follow-up.

Our genetic findings could be a direct result of differences in PAI-1 activity in airway remodelling. PAI-1 has been described to regulate tissue response and repair, by PAS inhibition [17]. 


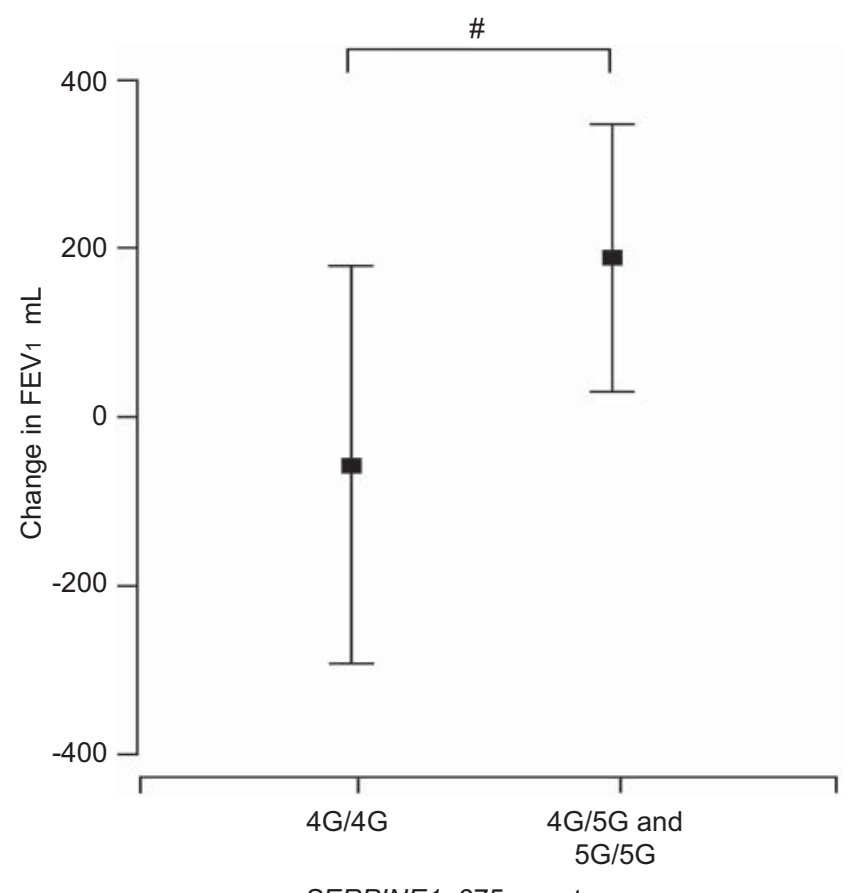

SERPINE1 -675 genotype

FIGURE 2. Change in forced expiratory volume in $1 \mathrm{~s}$ (FEV 1 ) after starting treatment with inhaled corticosteroids (ICSs) stratified by the SERPINE1 -675 4G/5G polymorphism (dominant genetic model). Results of linear mixed-effect model analyses. FEV 1 levels before the start of ICSs were set to zero per genotype group. Estimates and $p$-values from the analyses of the dominant genetic model $(4 \mathrm{G} / 4 \mathrm{G}$ group compared with the combined $4 \mathrm{G} / 5 \mathrm{G}$ and $5 \mathrm{G} / 5 \mathrm{G}$ groups) of the level of $F E V_{1}$ before the start of ICSs compared with the level of FEV 1 after the start of ICSs. Data are presented as mean $(95 \% \mathrm{Cl}) .{ }^{*}: \mathrm{p}=0.044$.

Higher levels of PAI-1 at the inflammatory site in association with pronounced airway remodelling may, therefore, lead to a lower lung function. The $4 \mathrm{G} / 5 \mathrm{G}$ polymorphism directly influences the level and activity of PAI-1 in plasma, and individuals with the $4 \mathrm{G}$ allele have higher plasma PAI-1 levels and activity [20, 21, 38, 39]. Differences in PAI-1 levels between the genotypes can therefore be involved in the development and progression of asthma. We show that asthmatics with the $4 \mathrm{G} / 5 \mathrm{G}$ or $5 \mathrm{G} / 5 \mathrm{G}$ genotype had a lower lung function level than those carrying the $4 \mathrm{G} / 4 \mathrm{G}$ genotype. Unfortunately, we have no data on serum PAI-1 levels and are thus unable to confirm higher PAI-1 levels in individuals with the $4 \mathrm{G}$ allele. Although some studies have described higher PAI-1 plasma levels to be associated with the $4 \mathrm{G}$ allele $[20,21,38,39]$, this has not been invariably shown $[12,40]$. Moreover, Stevens et al. [41] showed that PAI-1 expression and activity was increased in epithelial brushings of children with asthma, which was not reflected in plasma. Thus, the end result of SERPINE1 genotypes on the in situ activity, which may affect airway wall and lung tissue remodelling, remains to be determined. Furthermore, active smoking, alcohol, obesity, high serum triglycerides, male sex and age seem to increase PAI-1 levels, whilst regular exercise has been associated with lower PAI-1 levels [42-46]. This makes interpreting plasma PAI-1 level differences between the genotype groups difficult.
In our analysis, we found no significant difference in genotype distribution between asthma cases and nonasthmatic controls. Although this analysis is based on relatively few subjects, the remarkable similarity of the genotype distributions of the asthma cases and nonasthmatic controls implies that low study power is not driving this nonsignificance.

Our longitudinal study design allowed us to investigate the effect of SERPINE1 4G/5G polymorphism on the rate of FEV1 decline, especially in relation to the start of ICS treatment. As expected, we found a significant initial improvement in FEV1 after the start of ICS treatment. Interestingly, this improvement was largest in asthmatics having the $4 \mathrm{G} / 5 \mathrm{G}$ or $5 \mathrm{G} / 5 \mathrm{G}$ genotype, and absent in the $4 \mathrm{G} / 4 \mathrm{G}$ genotype group. This effect could not be driven by the fact that asthmatics carrying the $5 \mathrm{G}$ allele had a lower level of lung function than the $4 \mathrm{G} / 4 \mathrm{G}$ genotype group, since this was accounted for in the analysis.

From a pathophysiological perspective, the beneficial effects of the 5G genotype in ICS response might be due to differences in PAI-1 levels in the lungs. However, asthmatic subjects carrying the $5 \mathrm{G}$ allele had a more rapid annual decline in FEV1. ICS treatment did not reduce the difference between the genotype groups and subjects carrying the $5 \mathrm{G}$ allele still had a significantly more rapid annual FEV1 decline during ICS treatment compared to those carrying the $4 \mathrm{G} / 4 \mathrm{G}$ genotype. This implies that the short-term effects of ICS on FEV1 may be differentially regulated in a pathological respect than their long-term effects.

There exists an imbalance between MMPs and their inhibitors in asthma that contributes to airway remodelling [10, 11, 47], an important mechanism of accelerated lung function decline. Human mast cells are an important source of PAI-1 [18], a major inhibitor of MMPs, and pronounced activity of PAI-1 was reported to associate with pulmonary fibrosis [14-17]. Thus, PAI-1 may affect airway remodelling in asthma. CHO et al. [18] showed that sensitised mast cells release a considerable amount of PAI-1 and this was associated with blocking of fibrinolysis, thereby promoting fibrin and collagen deposition, which is a feature of airway remodelling [18]. It is tempting to speculate that ICS use will lead to a reduction of PAI-1 activity, since steroids suppress degranulation and cytokine production in mast cells potently in vitro in a time-dependent manner [48-51]. So far, conflicting results have been reported on the effects of steroids on PAI-1 production by cells in vitro, which may largely be due to the type of cell being studied and timing of effect measurements. Incubation with glucocorticoids for $2-$ $8 \mathrm{~h}$ resulted in increased PAI-1 levels in keratinocytes and human lung fibroblasts [52-54], and partial suppression of fibrinolytic activity in pulmonary alveolar epithelial cells [55]. In contrast, after an initially increased PAI-1 activity by glucocorticosteroids in human adipose tissue fragments, a significant reduction in PAI-1 activity and mRNA expression occurred after a further 48-h incubation [56]. Finally, there is most probably no simple answer to the question of in what way ICS use influences PAI-1 levels and activity at the bronchial epithelial level, especially since other anti-inflammatory effects of ICSs, such as suppression of cytokine release, are also influencing PAI-1 expression and activity. Thus, short-term beneficial effects on lung function may result from regulation at different cellular levels rather than the lack of difference in FEV1 decline with glucocorticosteroids in relation to PAI-1 genotypes. 
Many studies have investigated which factors determine the progression or severity of asthma, especially since severe asthma largely drives the economic costs of asthma management. However, it is also of importance to get insight in the driving factors of asthma remission. Here, we found that asthma remission, defined as the absence of asthma symptoms, normal lung function, absence of hyperresponsiveness and no use of asthma treatment, occurred in $11 \%$ of our asthma population. For the first time, we suggest that remission of asthma may be genetically determined. Asthmatics with the 5G allele of SERPINE1 had the lowest prevalence of remission and those with the $4 \mathrm{G} / 4 \mathrm{G}$ genotype the highest prevalence. Again, this may reflect differences in chronic airway inflammation and remodelling between genotypes.

Higher serum IgE levels have been associated with the $4 \mathrm{G}$ allele of the SERPINE1 4G/5G polymorphism [12, 57]. We found higher $\operatorname{IgE}$ levels in those carrying the $5 \mathrm{G}$ allele. However, we found no association of the SERPINE1 4G/5G polymorphism with serum total $\mathrm{IgE}$ in the control groups or with asthma in the case-control analyses. Therefore, we believe SERPINE1 is not an asthma susceptibility gene and does not solely carry the risk of higher $\operatorname{IgE}$ levels in asthma. Thus, SERPINE1 is not the gene by which we can explain our previously found linkage on chromosome 7q21 [19].

In accordance with previous studies, the $4 \mathrm{G}$ allele was the most prevalent allele in our populations [12, 23, 24, 58]. In our study, we found the $5 \mathrm{G}$ allele carried the risk of development of more severe asthma, reflected by lung function impairment, response to ICS use and lower prevalence of asthma remission. Others found that the $4 \mathrm{G}$ allele was associated with asthma and lower lung function in asthmatic patients [12]. These discrepant findings may be due to population stratification. Asthma is a complex disease in which genetic and environmental factors contribute to the asthma phenotype. Geneenvironment interactions are extremely complex and not always linear, such that the same genetic variants might be associated with opposite phenotypes in different environments [59]. This might be the case in our population; although we have no direct signs of which contributing factors may account for the conflicting findings. Another explanation may be that the real causal variant in the SERPINE1 gene is not the polymorphism we genotyped but another polymorphism that is in linkage disequilibrium (LD) with the $4 \mathrm{G} / 5 \mathrm{G}$ polymorphism. This LD structure may differ between populations and, therefore, we found different risk allele to previous studies.

A recent linkage and association study identified the plasma urokinase plasminogen activator receptor (PLAUR) gene in chromosome $19 \mathrm{q} 13.1-3$ as a potential asthma susceptibility gene [60]. Polymorphisms in the PLAUR gene were associated with asthma, AHR, FEV1 and plasma levels of PLAUR (also known as UPAR) [60]. PLAUR interacts with urokinase plasminogen activator, resulting in enhanced activation of cell-bound plasminogen [61] and, therefore, plays a role in PAS. PLAUR has been implicated in many physiological processes, including cell migration, proliferation, differentiation and tissue fibrosis [62]. These findings further support those of the present study on SERPINE1 polymorphism and asthma, implying that PAS is a candidate pathway for enhanced airway remodelling in asthma.
We conclude that our findings may suggest a role of the SERPINE1 gene in the progression, remission and severity of asthma, probably via the effects of PAI-1 on airway inflammation and remodelling. Clearly, functional studies need to address the exact contribution of PAI-1 in this process and the interaction with ICS treatment.

\section{SUPPORT STATEMENT}

This study was supported by the Netherlands Asthma Foundation (grants AF 93.66 and AF 3.2.00.38).

\section{STATEMENT OF INTEREST}

Statements of interest for D.S. Postma and G.H. Koppelman can be found at www.erj.ersjournals.com/site/misc/statements.xhtml

\section{REFERENCES}

1 Grol MH, Gerritsen J, Vonk JM, et al. Risk factors for growth and decline of lung function in asthmatic individuals up to age 42 years. A 30-year follow-up study. Am J Respir Crit Care Med 1999; 160: $1830-1837$

2 Lange P, Parner J, Vestbo J, et al. A 15-year follow-up study of ventilatory function in adults with asthma. $N$ Engl J Med 1998; 339: 1194-1200.

3 Ulrik CS, Lange P. Decline of lung function in adults with bronchial asthma. Am J Respir Crit Care Med 1994; 150: 629-634.

4 Vonk JM, Jongepier $\mathrm{H}$, Panhuysen CI, et al. Risk factors associated with the presence of irreversible airflow limitation and reduced transfer coefficient in patients with asthma after 26 years of follow up. Thorax 2003; 58: 322-327.

5 Dijkstra A, Vonk JM, Jongepier $\mathrm{H}$, et al. Lung function decline in asthma: association with inhaled corticosteroids, smoking and sex. Thorax 2006; 61: 105-110.

6 Vonk JM, Postma DS, Boezen HM, et al. Childhood factors associated with asthma remission after 30 year follow up. Thorax 2004; 59: 925-929.

7 Panhuysen CI, Vonk JM, Koëter GH, et al. Adult patients may outgrow their asthma: a 25-year follow-up study. Am J Respir Crit Care Med 1997; 155: 1267-1272.

8 Broekema M, Timens W, Vonk JM, et al. Persisting remodeling and less airway wall eosinophil activation in complete remission of asthma. Am J Respir Crit Care Med 2010; 183: 310-316.

9 Elias JA, Zhu Z, Chupp G, et al. Airway remodeling in asthma. J Clin Invest 1999; 104: 1001-1006.

10 Busse WW, Lemanske RF Jr. Asthma. N Engl J Med 2001; 344: 350-362.

11 Tattersfield AE, Knox AJ, Britton JR, et al. Asthma. Lancet 2002; 360: 1313-1322.

12 Pampuch A, Kowal K, Bodzenta-Lukaszyk A, et al. The -675 4G/ $5 \mathrm{G}$ plasminogen activator inhibitor-1 promoter polymorphism in house dust mite-sensitive allergic asthma patients. Allergy 2006; 61: 234-238

13 Kowal K, Zukowski S, Moniuszko M, et al. Plasminogen activator inhibitor-1 (PAI-1) and urokinase plasminogen activator (uPA) in sputum of allergic asthma patients. Folia Histochem Cytobiol 2008; 46: 193-198.

14 Eitzman DT, McCoy RD, Zheng X, et al. Bleomycin-induced pulmonary fibrosis in transgenic mice that either lack or overexpress the murine plasminogen activator inhibitor-1 gene. J Clin Invest 1996; 97: 232-237.

15 Hattori N, Degen JL, Sisson $\mathrm{TH}$, et al. Bleomycin-induced pulmonary fibrosis in fibrinogen-null mice. J Clin Invest 2000; 106: 1341-1350.

16 Eddy AA, Fogo AB. Plasminogen activator inhibitor-1 in chronic kidney disease: evidence and mechanisms of action. J Am Soc Nephrol 2006; 17: 2999-3012. 
17 Kucharewicz I, Kowal K, Buczko W, et al. The plasmin system in airway remodeling. Thromb Res 2003; 112: 1-7.

18 Cho SH, Tam SW, Demissie-Sanders S, et al. Production of plasminogen activator inhibitor-1 by human mast cells and its possible role in asthma. J Immunol 2000; 165: 3154-3161.

$19 \mathrm{Xu}$ J, Postma DS, Howard TD, et al. Major genes regulating total serum immunoglobulin E levels in families with asthma. Am J Hum Genet 2000; 67: 1163-1173.

20 Burzotta F, Di CA, Amore C, et al. 4G/5G promoter PAI-1 gene polymorphism is associated with plasmatic PAI-1 activity in Italians: a model of gene-environment interaction. Thromb Haemost 1998; 79: 354-358.

21 Dawson SJ, Wiman B, Hamsten A, et al. The two allele sequences of a common polymorphism in the promoter of the plasminogen activator inhibitor-1 (PAI-1) gene respond differently to interleukin-1 in HepG2 cells. J Biol Chem 1993; 268: 10739-10745.

22 Buckova D, Izakovicova HL, Vacha J. Polymorphism 4G/5G in the plasminogen activator inhibitor-1 (PAI-1) gene is associated with IgE-mediated allergic diseases and asthma in the Czech population. Allergy 2002; 57: 446-448.

23 Cho SH, Hall IP, Wheatley A, et al. Possible role of the 4G/5G polymorphism of the plasminogen activator inhibitor 1 gene in the development of asthma. J Allergy Clin Immunol 2001; 108: 212-214.

24 Cho SH, Ryu CH, Oh CK. Plasminogen activator inhibitor-1 in the pathogenesis of asthma. Exp Biol Med (Maywood) 2004; 229: 138-146.

25 Bajou K, Noel A, Gerard RD, et al. Absence of host plasminogen activator inhibitor 1 prevents cancer invasion and vascularization. Nat Med 1998; 4: 923-928.

26 Shapiro RL, Duquette JG, Roses DF, et al. Induction of primary cutaneous melanocytic neoplasms in urokinase-type plasminogen activator (uPA)-deficient and wild-type mice: cellular blue nevi invade but do not progress to malignant melanoma in uPAdeficient animals. Cancer Res 1996; 56: 3597-3604.

27 Stefansson S, Lawrence DA. The serpin PAI-1 inhibits cell migration by blocking integrin alpha $\mathrm{V}$ beta 3 binding to vitronectin. Nature 1996; 383: 441-443.

28 de Vries K, Goei J, Booy-Noord H, et al. Changes during 24 hours in the lung function and histamine hyperreactivity of the bronchial tree in asthmatic and bronchitic patients. Int Arch Allergy Appl Immunol 1962; 20: 93-101.

29 Panhuysen CI, Bleecker ER, Koëter GH, et al. Characterization of obstructive airway disease in family members of probands with asthma. An algorithm for the diagnosis of asthma. Am J Respir Crit Care Med 1998; 157: 1734-1742.

30 van Diemen CC, Postma DS, Vonk JM, et al. A disintegrin and metalloprotease 33 polymorphisms and lung function decline in the general population. Am J Respir Crit Care Med 2005; 172: 329-333.

31 Jansen DF, Schouten JP, Vonk JM, et al. Smoking and airway hyperresponsiveness especially in the presence of blood eosinophilia increase the risk to develop respiratory symptoms: a 25-year follow-up study in the general adult population. Am J Respir Crit Care Med 1999; 160: 259-264.

32 van der Lende R, Orie NG. The MRC-ECCS questionnaire on respiratory symptoms (use in epidemiology). Scand J Respir Dis 1972; 53: 218-226.

33 Mensinga TT, Schouten JP, Rijcken B, et al. The relationship of eosinophilia and positive skin test reactivity to respiratory symptom prevalence in a community-based population study. J Allergy Clin Immunol 1990; 86: 99-107.

34 Rijcken B, Schouten JP, Weiss ST, et al. The relationship between airway responsiveness to histamine and pulmonary function level in a random population sample. Am Rev Respir Dis 1988; 137: 826-832.

35 Rijcken B, Weiss ST. Longitudinal analyses of airway responsiveness and pulmonary function decline. Am J Respir Crit Care Med 1996; 154: S246-S249.
36 Laird NM, Ware JH. Random-effects models for longitudinal data. Biometrics 1982; 38: 963-974.

37 Kerstjens HA, Brand PL, Hughes MD, et al. A comparison of bronchodilator therapy with or without inhaled corticosteroid therapy for obstructive airways disease. Dutch Chronic NonSpecific Lung Disease Study Group. N Engl J Med 1992; 327: 1413-1419.

38 Kucukarabaci B, Gunes HV, Ozdemir G, et al. Investigation of association between plasminogen activator inhibitor type-1 (PAI-1) gene 4G/5G polymorphism frequency and plasma PAI-1 enzyme activity in patients with acute stroke. Genet Test 2008; 12: 443-451.

39 Stegnar M, Uhrin P, Peternel P, et al. The 4G/5G sequence polymorphism in the promoter of plasminogen activator inhibitor-1 (PAI-1) gene: relationship to plasma PAI-1 level in venous thromboembolism. Thromb Haemost 1998; 79: 975-979.

40 Leander K, Wiman B, Hallqvist J, et al. PAI-1 level and the PAI-1 $4 \mathrm{G} / 5 \mathrm{G}$ polymorphism in relation to risk of non-fatal myocardial infarction: results from the Stockholm Heart Epidemiology Program (SHEEP). Thromb Haemost 2003; 89: 1064-1071.

41 Stevens PT, Kicic A, Sutanto EN, et al. Dysregulated repair in asthmatic paediatric airway epithelial cells: the role of plasminogen activator inhibitor-1. Clin Exp Allergy 2008; 38: 1901-1910.

42 Mertens I, Van Gaal LF. Obesity, haemostasis and the fibrinolytic system. Obes Rev 2002; 3: 85-101.

43 Margaglione M, Cappucci G, d'Addedda M, et al. PAI-1 plasma levels in a general population without clinical evidence of atherosclerosis: relation to environmental and genetic determinants. Arterioscler Thromb Vasc Biol 1998; 18: 562-567.

44 Vaisanen SB, Humphries SE, Luong LA, et al. Regular exercise, plasminogen activator inhibitor-1 (PAI-1) activity and the 4G/5G promoter polymorphism in the PAI-1 gene. Thromb Haemost 1999; 82: 1117-1120.

45 Bonfigli AR, Sirolla C, Cenerlli S, et al. Plasminogen activator inhibitor-1 plasma level increases with age in subjects with the $4 \mathrm{G}$ allele at position -675 in the promoter region. Thromb Haemost 2004; 92: 1164-1165.

46 Yarnell JW, Sweetnam PM, Rumley A, et al. Lifestyle and hemostatic risk factors for ischemic heart disease: the Caerphilly Study. Arterioscler Thromb Vasc Biol 2000; 20: 271-279.

47 Vignola AM, Riccobono L, Mirabella A, et al. Sputum metalloproteinase- $9 /$ tissue inhibitor of metalloproteinase-1 ratio correlates with airflow obstruction in asthma and chronic bronchitis. Am J Respir Crit Care Med 1998; 158: 1945-1950.

48 Andrade MV, Hiragun T, Beaven MA. Dexamethasone suppresses antigen-induced activation of phosphatidylinositol 3-kinase and downstream responses in mast cells. J Immunol 2004; 172: 7254-7262.

49 Berenstein EH, Garcia-Gil M, Siraganian RP. Dexamethasone inhibits receptor-activated phosphoinositide breakdown in rat basophilic leukemia (RBL-2H3) cells. J Immunol 1987; 138: 19141918.

50 Daëron M, Sterk AR, Hirata F, et al. Biochemical analysis of glucocorticoid-induced inhibition of IgE-mediated histamine release from mouse mast cells. J Immunol 1982; 129: 1212-1218.

51 Nakamura R, Okunuki H, Ishida S, et al. Gene expression profiling of dexamethasone-treated RBL-2H3 cells: induction of antiinflammatory molecules. Immunol Lett 2005; 98: 272-279.

52 Bator JM, Cohen RL, Chambers DA. Hydrocortisone regulates the dynamics of plasminogen activator and plasminogen activator inhibitor expression in cultured murine keratinocytes. Exp Cell Res 1998; 242: 110-119.

53 Samad F, Bergtrom G, Amrani DL. Regulation of plasminogen activation by interleukin-6 in human lung fibroblasts. Biochim Biophys Acta 1994; 1221: 307-314.

54 Van Zaane B, Nur E, Squizzato A, et al. Systematic review on the effect of glucocorticoid use on procoagulant, anti-coagulant and fibrinolytic factors. J Thromb Haemost 2010; 8: 2483-2493. 
55 Simon RH, Gross TJ, Edwards JA, et al. Fibrin degradation by rat pulmonary alveolar epithelial cells. Am J Physiol 1992; 262: L482-L488.

56 He G, Pedersen SB, Bruun JM, et al. Regulation of plasminogen activitor inhibitor-1 in human adipose tissue: interaction between cytokines, cortisol and oestrogen. Horm Metab Res 2000; 32: 515-520.

57 Kowal K, Bodzenta-Lukaszyk A, Pampuch A, et al. Plasminogen activator inhibitor-1 plasma concentration in allergic asthma patients during allergen challenge. Int Arch Allergy Immunol 2007; 144: 240-246.

58 Festa A, D'Agostino R, Jr, Rich SS, et al. Promoter (4G/5G) plasminogen activator inhibitor-1 genotype and plasminogen activator inhibitor-1 levels in blacks, Hispanics, and nonHispanic whites: the Insulin Resistance Atherosclerosis Study. Circulation 2003; 107: 2422-2427.

59 Vercelli D. Genetics, epigenetics, and the environment: switching, buffering, releasing. J Allergy Clin Immunol 2004; 113: 381-386.

60 Barton SJ, Koppelman GH, Vonk JM, et al. PLAUR polymorphisms are associated with asthma, PLAUR levels, and lung function decline. J Allergy Clin Immunol 2009; 123: 1391-1400.

61 Dear AE, Medcalf RL The urokinase-type-plasminogen-activator receptor (CD87) is a pleiotropic molecule. Eur J Biochem 1998; 252: 185-193.

62 Blasi F, Carmeliet P. uPAR: a versatile signalling orchestrator. Nat Rev Mol Cell Biol 2002; 3: 932-943. 